Article

\title{
Unsupported nanoporous palladium-catalyzed chemoselective hydrogenation of quinolines: Heterolytic cleavage of $\mathrm{H}_{2}$ molecule
}

\author{
Ye Lu a, Yoshinori Yamamoto a,b,c, Abdulrahman I. Almansour d, Natarajan Arumugam d, \\ Raju Suresh Kumard, Ming Bao a,* \\ a State Key Laboratory of Fine Chemicals, Dalian University of Technology, Dalian 116023, Liaoning, China \\ b Department of Chemistry, Graduate School of Science, Tohoku University, Sendai 980-8578, Japan \\ c Research Organization of Science and Technology, Ritsumeikan University, Kusatsu, Shiga 525-8577, Japan \\ d Department of Chemistry, College of Sciences, King Saud University, P.O. Box 2455, Riyadh 11451, Saudi Arabia
}

\section{A R T I C L E I N F}

\section{Article history:}

Received 26 June 2018

Accepted 29 July 2018

Published 5 November 2018

\section{Keywords:}

Nanoporous materials

Palladium

Quinolines

Chemoselective hydrogenation

Heterogeneous catalyst

\begin{abstract}
A B S T R A C T
An efficient and highly chemoselective heterogeneous catalyst system for quinoline hydrogenation was developed using unsupported nanoporous palladium (PdNPore). The PdNPore-catalyzed chemoselective hydrogenation of quinoline proceeded smoothly under mild reaction conditions (low $\mathrm{H}_{2}$ pressure and temperature) to yield 1,2,3,4-tetrahydroquinolines (py-THQs) in satisfactory to excellent yields. Various synthetically useful functional groups, such as halogen, hydroxyl, formyl, ethoxycarbonyl, and aminocarbonyl groups, remained intact during the quinoline hydrogenation. No palladium was leached from PdNPore during the hydrogenation reaction. Moreover, the catalyst was easily recovered and reused without any loss of catalytic activity. The results of kinetic, deuterium-hydrogen exchange, and deuterium-labeling experiments indicated that the present hydrogenation involves heterolytic $\mathrm{H}_{2}$ splitting on the surface of the catalyst.
\end{abstract}

(C) 2018, Dalian Institute of Chemical Physics, Chinese Academy of Sciences. Published by Elsevier B.V. All rights reserved.

\section{Introduction}

Hydrogenation of unsaturated bonds is an important approach for molecular functionalization [1-5]. The hydrogenation of polar unsaturated bonds is often carried out using homogeneous catalysts; this process generates metal hydride $(\mathrm{M}-\mathrm{H})$ species in situ through the heterolysis of hydrogen molecules $\left(\mathrm{H}_{2}\right)[6,7]$. Heterogeneous catalysts have been widely used in the industry because of their stability, reusability, and easy separation. The hydrogenation of nonpolar unsaturated bonds can be easily achieved on the surface of heterogeneous catalysts and involves the homolysis of $\mathrm{H}_{2}$ [8]. However, the hydrogenation of polar unsaturated bonds, which proceeds at mild conditions (low $\mathrm{H}_{2}$ pressure and temperature) using a heterogeneous catalyst, remains challenging. Compared with heterolytic splitting, homolytic $\mathrm{H}_{2}$ splitting can occur easily on the surface of heterogeneous catalysts.

The chemoselective hydrogenation of quinolines to obtain 1,2,3,4-tetrahydroquinolines (py-THQs), which is an important framework in numerous pharmaceuticals, agrochemicals, dyes, and biologically active natural products [9], has been demonstrated. This process is the most convenient and promising technique to produce py-THQs, because of its high atom utilization and the easy availability of the raw material [10]. Many

\footnotetext{
* Corresponding author. Tel: +86-411-84986180; Fax: +86-411-84986181; E-mail: mingbao@dlut.edu.cn

This work was supported by the National Natural Science Foundation of China (21573032, 21773021), the Fundamental Research Funds for the Central Universities (DUT17ZD212), and the International Scientific Partnership Program ISPP at King Saud University for funding this research work through ISPP\#0048.

DOI: 10.1016/S1872-2067(18)63151-1 | http://www.sciencedirect.com/science/journal/18722067 | Chin. J. Catal., Vol. 39 , No. 11 , November 2018
} 
types of homogeneous [11-19] and heterogeneous [20-35] catalyst systems have been developed for the chemoselective hydrogenation of quinolines. Although heterogeneous catalyst systems have recently attracted considerable attention and are successfully employed in the chemoselective hydrogenation of quinolines (Scheme 1), relatively high $\mathrm{H}_{2}$ pressures (10-50 atm) and high reaction temperatures $\left(60-150{ }^{\circ} \mathrm{C}\right)$ are required. Therefore, hydrogenation under much milder conditions is highly desirable. In addition, no evidence was found for the heterolytic $\mathrm{H}_{2}$ splitting on the surface of heterogeneous catalysts during the hydrogenation of quinolines.

Catalysts based on unsupported nanoporous metal materials are attracting considerable interest because of their "green" potential and sustainable catalytic properties [36,37]. Nanoporous metals are attractive as heterogeneous catalysts because of their nontoxicity, robustness, high recyclability, and easy recovery. We have previously demonstrated that nanoporous metals are promising green heterogeneous catalysts for liquid-phase organic synthesis [38-41]. In the present work, we investigated the hydrogenation of quinolines using PdNPore as a catalyst. The chemoselective hydrogenation of quinolines proceeded smoothly under relatively low $\mathrm{H}_{2}$ pressures (2-5 atm) and temperatures (room temperature to $50{ }^{\circ} \mathrm{C}$ ), to give py-THQs in satisfactory to excellent yields without leaching of palladium (Scheme 1). The results of a mechanistic analysis show that the chemoselective hydrogenation of quinolines involves heterolysis of $\mathrm{H}_{2}$.

\section{Experimental}

\subsection{General}

The starting materials were purchased from Energy Chemicals Co., Ltd. Solvents were purified by standard techniques without special instructions. All other reagents were used as received. ${ }^{1} \mathrm{H}$ and ${ }^{13} \mathrm{C}$ NMR spectra were recorded on either a Varian Inova-400 (400 MHz for ${ }^{1} \mathrm{H}, 100 \mathrm{MHz}$ for $\left.{ }^{13} \mathrm{C}\right)$ or a Bruker Avance II-400 (400 MHz for ${ }^{1} \mathrm{H}, 100 \mathrm{MHz}$ for ${ }^{13} \mathrm{C}$ ) spectrometer; $\mathrm{CDCl}_{3}$ was used as a solvent, while tetramethylsilane (TMS) was used as an internal standard. In the following, chemical shifts are reported in ppm downfield $(\delta)$ from TMS, whereas the coupling constants $J$ are expressed in Hz. The peak patterns are labeled as follows: s, singlet; $d$, doublet; $t$, triplet; $q$, quartet; $\mathrm{m}$, multiplet. Thin-layer chromatography (TLC) was carried out on $\mathrm{SiO}_{2}$ (silica gel $60 \mathrm{~F} 254$, Merck), and the spots were located with UV light, iodoplatinate reagent, or $1 \%$ aque-

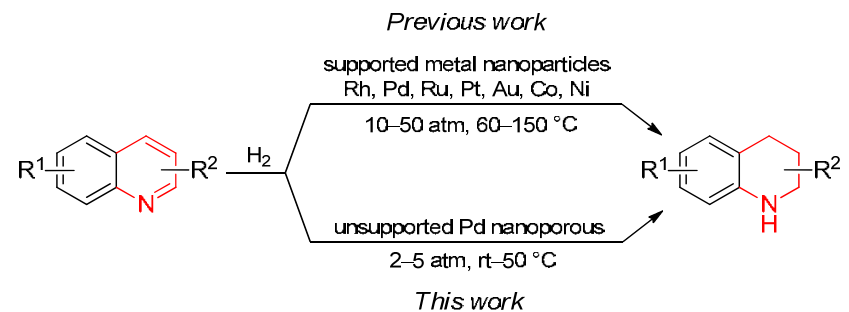

Scheme 1. PdNPore-catalyzed hydrogenation of nitrogen-containing heteroaromatic compounds. ous $\mathrm{KMnO}_{4}$. Flash chromatography was carried out on $\mathrm{SiO}_{2}$ (silica gel 60, 200-300 mesh).

\section{Results and discussion}

The hydrogenation of quinoline (1a, Table 1$)$ in the presence of PdNPore ( $5 \mathrm{~mol} \%$ ) was chosen as a model in preliminary tests aimed to optimize the reaction conditions. The results are shown in Table 1. It was expected that a polar and Lewis-basic solvent could assist the heterolytic cleavage of $\mathrm{H}-\mathrm{H}$ bonds, facilitating the chemoselective hydrogenation of quinoline to py-THQ [24,42]. Accordingly, the reduction was initially tested in polar and Lewis-basic solvents, dimethylformamide (DMF), and 1,4-dioxane (Dioxane), under $5 \mathrm{~atm} \mathrm{H}_{2}$ at room temperature. As expected, 2a was obtained as the sole product in moderate yields (entries 1 and 2, 55\% and 51\%, respectively). The yield of $\mathbf{2 a}$ decreased when toluene, a nonpolar solvent, was used (entry 3, 30\%). In contrast, the yield of $2 \mathbf{a}$ increased to $72 \%$ by adding triethylamine $\left(\mathrm{Et}_{3} \mathrm{~N}\right)$, a polar and Lewis-basic additive, to toluene (entry 4). Thus, $\mathrm{Et}_{3} \mathrm{~N}$ was used as the solvent, and the yield of 2a further increased (entry 5, 80\%). The desired product 2a was finally obtained in excellent yield (93\%) when acetonitrile $\left(\mathrm{CH}_{3} \mathrm{CN}\right)$ was used as a solvent (entry 6); in this case, ethylamine $(1.5 \mathrm{mmol})$ was also obtained. These results indicate that $\mathrm{CH}_{3} \mathrm{CN}$ was hydrogenated to the corresponding amine under the reaction conditions. The obtained ethylamine may act as a polar and Lewis-basic additive, in addition to $\mathrm{CH}_{3} \mathrm{CN}$ itself. The yield decreased when the $\mathrm{H}_{2}$

Table 1

Reaction conditions screening a.

\begin{tabular}{|c|c|c|c|}
\hline Entry & Catalyst & Solvent & Yield b $(\%)$ \\
\hline 1 & PdNPore & DMF & 55 \\
\hline 2 & PdNPore & Dioxane & 51 \\
\hline 3 & PdNPore & Toluene & 30 \\
\hline $4^{c}$ & PdNPore & Toluene & 72 \\
\hline 5 & PdNPore & $\mathrm{Et}_{3} \mathrm{~N}$ & 80 \\
\hline $6^{\mathrm{d}}$ & PdNPore & $\mathrm{CH}_{3} \mathrm{CN}$ & 93 \\
\hline $7 \mathrm{e}$ & PdNPore & $\mathrm{CH}_{3} \mathrm{CN}$ & 84 \\
\hline $8^{f}$ & PdNPore & $\mathrm{CH}_{3} \mathrm{CN}$ & 76 \\
\hline $9 \mathrm{~g}$ & PdNPore & $\mathrm{CH}_{3} \mathrm{CN}$ & 57 \\
\hline 10 & None & $\mathrm{CH}_{3} \mathrm{CN}$ & $\mathrm{NR}^{\mathrm{h}}$ \\
\hline 11 & $\mathrm{Pd}_{20} \mathrm{Al}_{80}$ alloy & $\mathrm{CH}_{3} \mathrm{CN}$ & $\mathrm{NR}^{\mathrm{h}}$ \\
\hline $12^{\mathrm{i}}$ & $\mathrm{Pd} / \mathrm{C}$ & $\mathrm{CH}_{3} \mathrm{CN}$ & 34 \\
\hline$\underline{13}{ }^{i}$ & Lindlar Pd & $\mathrm{CH}_{3} \mathrm{CN}$ & 52 \\
\hline \multicolumn{4}{|c|}{ 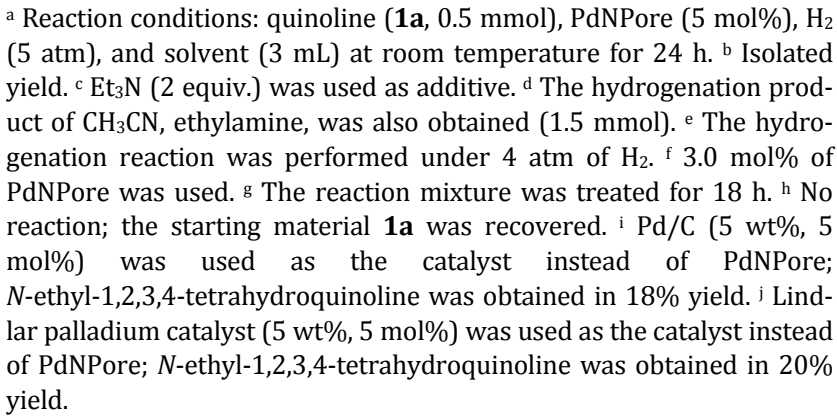 } \\
\hline
\end{tabular}


pressure and catalyst loading were decreased (entries 7 and 8). The yield of the $\mathbf{2 a}$ product also decreased with a shorter reaction time (entry 9). No reaction was observed in the absence of PdNPore catalyst or when the precursor of PdNPore, the $\mathrm{Pd}_{20} \mathrm{Al}_{80}$ alloy, was used in the hydrogenation of $\mathbf{1 a}$ (entries 10 and 11). Accordingly, we set the standard conditions as follows: PdNPore (5 mol\%), 5 atm $\mathrm{H}_{2}$, and room temperature in $\mathrm{CH}_{3} \mathrm{CN}$. The desired 2a product was separated in low yield, along with a $N$-ethyl-1,2,3,4-tetrahydroquinoline byproduct, when the palladium/carbon and the Lindlar palladium catalysts were used instead of the PdNPore catalyst (entries 12 and 13). These results clearly indicate that the activity and selectivity of the PdNPore catalyst are higher than those of the two commercially available catalysts.

The catalytic activity of PdNPore was further examined by using it for the hydrogenation of various substituted quinolines under the same conditions described above (Table 2). Monomethyl-substituted quinolines were chemoselectively hydrogenated to give the corresponding py-THQs in good to excellent yields, regardless of the position of the methyl substituent on the benzene or pyridine ring (entries 2-6, 2b-2f, 81\%-95\%). Compared with the quinolines 1a-1f, the substrate 1g, bearing two methyl groups on the 2- and 6-positions, exhibited relatively low reactivity and required slight heating to undergo the hydrogenation reaction. Product $2 \mathbf{g}$ was obtained in $62 \%$ yield (entry 7). Similarly, the quinolines $\mathbf{1 h}$ and $\mathbf{1 i}$, bearing a strong electron-donating methoxy $(\mathrm{MeO})$ group on the 5- or 6-position, also required slight heating to complete the hydrogenation reaction. The corresponding products $\mathbf{2 h}$ and $2 \mathbf{i}$ were obtained in good yields $(84 \%$ and $80 \%$, respectively; entries 8 and 9). Interestingly, 8-hydroxyquinoline (1j) smoothly underwent chemoselective hydrogenation at room temperature to yield the desired product $\mathbf{2} \mathbf{j}$ in $83 \%$ yield, despite bearing a strong electron-donating hydroxyl $(\mathrm{OH})$ group on the 8-position [43]. This behavior could be attributed to the formation of intramolecular hydrogen bonds in substrate $\mathbf{1 j}$ (entry 10). The substrate $\mathbf{1 k}$, an acylated derivative of $\mathbf{1 j}$, exhibited higher reactivity than its precursor $\mathbf{1 j}$, giving the product $2 \mathbf{k}$ in excellent yield (entry 11, 92\%). Remarkably, the fluoro- and chloro-substituted quinolines 1l-1n smoothly underwent the desired chemoselective hydrogenation reaction under reduced $\mathrm{H}_{2}$ pressure, to afford the corresponding products $\mathbf{2 l - 2 n}$ in satisfactory to good yields without generating the dehalogenated product (entries 12-14, 2 atm of $\mathrm{H}_{2}, 72 \%-83 \%$ ). However, debromination was observed when the bromine-containing substrate bromoquinoline (10) was employed under optimal conditions. The desired hydrogenation product 20 was obtained in 71\% yield, along with the debromination product $\mathbf{2 a}$ in $8 \%$ yield (entry 15 ). Finally, the $\mathbf{1 p - 1 r}$ substrates, bearing electron-withdrawing and reducible groups such as formyl, ethoxycarbonyl, and aminocarbonyl, were tested. These substrates exhibited higher reactivity in the chemoselective hydrogenation reaction than those bearing electron-donating groups. The products $\mathbf{2} \mathbf{p}-\mathbf{2 r}$ were obtained in $80 \%-85 \%$ yields under reduced $\mathrm{H}_{2}$ pressure. No reduction of the functional groups was observed, suggesting that further manipulation may produce more useful compounds (entries
Table 2

PdNPore-catalyzed hydrogenation of various quinolines a

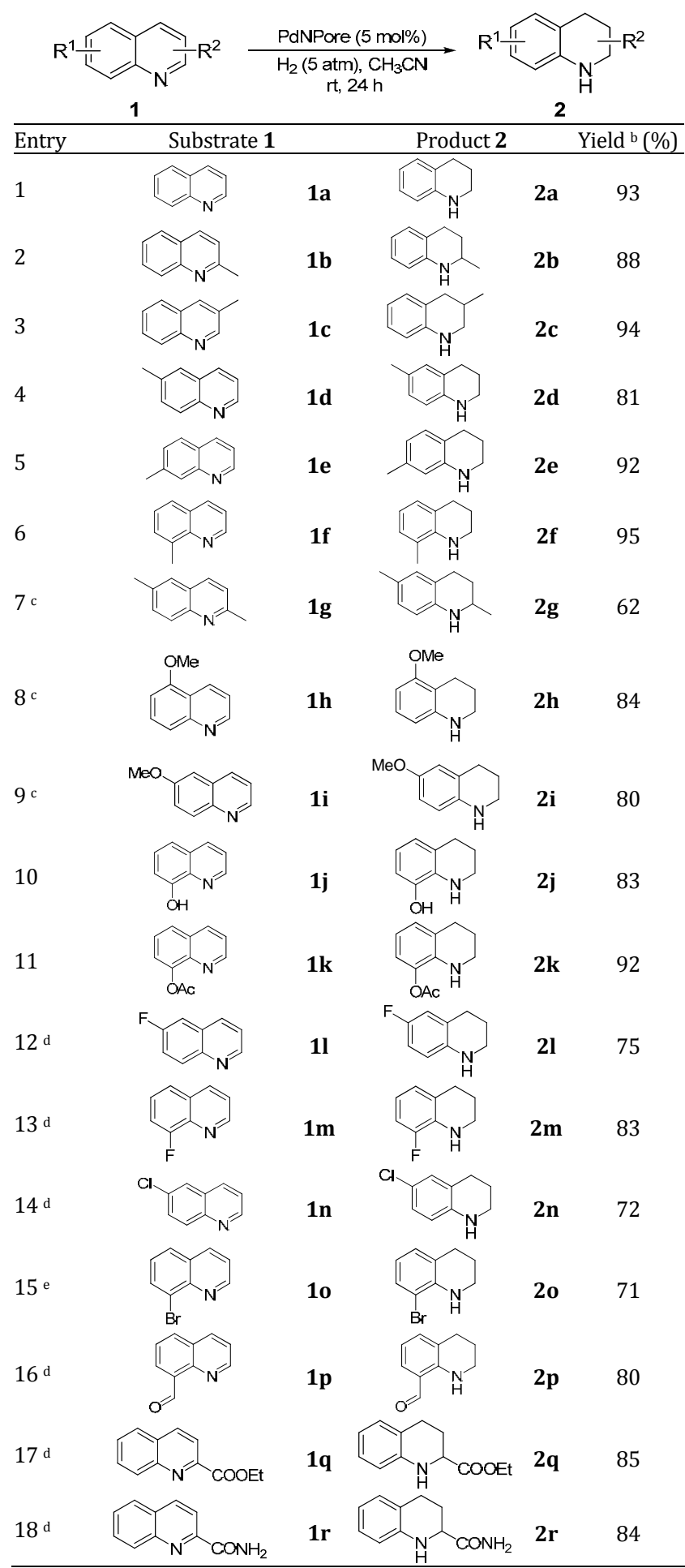

a Reaction conditions: PdNPore (5 mol\%), 1 (0.5 mmol), $\mathrm{H}_{2}(5 \mathrm{~atm})$ in $\mathrm{CH}_{3} \mathrm{CN}$ at room temperature for $24 \mathrm{~h}$. ${ }^{\mathrm{b}}$ Isolated yield. ${ }^{\mathrm{c}}$ The hydrogenation reaction was conducted at $50{ }^{\circ} \mathrm{C}$. $\mathrm{d}$ The hydrogenation reaction was performed under $2 \mathrm{~atm}$ of $\mathrm{H}_{2}{ }^{\text {e }}$ Debromination took place to produce 2a in $8 \%$ yield.

16-18).

Several nitrogen-containing heteroaromatic compounds were examined under optimized or slightly modified reaction 


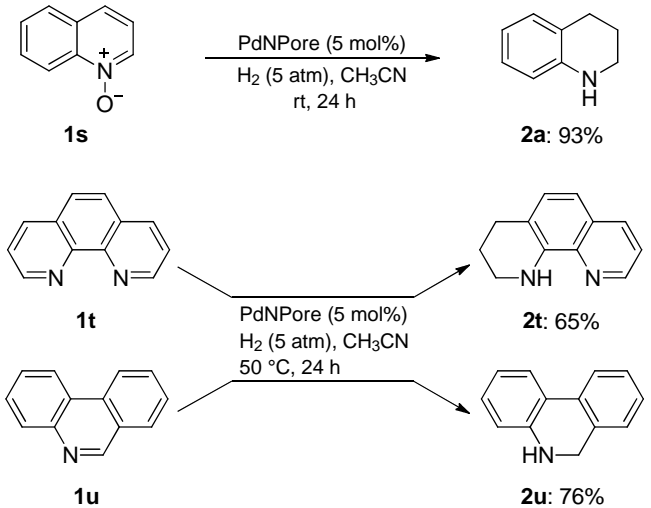

(1)<smiles>c1ccc2ncccc2c1</smiles>

1a: $1.29 \mathrm{~g}$

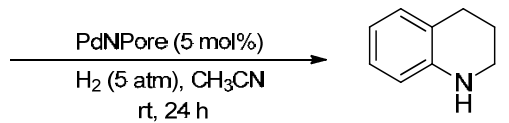

$\mathrm{rt}, 24 \mathrm{~h}$

2a: $1.16 \mathrm{~g}(87 \%)$

Scheme 4. PdNPore-catalyzed gram-scale hydrogenation of $\mathbf{1 a}$.

The stability of the PdNPore catalyst was further investigated by recycling tests, and the results are summarized in Table 3. Almost the same yields were observed in the hydrogenation of quinoline (1a) under standard conditions when the PdNPore catalyst was reused for six times. These results clearly indicate that PdNPore is a robust and recyclable catalyst.

Kinetic tests were performed to investigate the effect of ethylamine and py-THQ in the hydrogenation of quinolines. The results are shown in Fig. 1. The yield of the py-THQ 2a product was determined to be $30 \%$ in the first $12 \mathrm{~h}$, and the decrease in the starting material 1a showed a very good correlation with the formation of $\mathbf{2 a}$. However, the yield of $\mathbf{2 a}$ increased to $93 \%$ in the second $12 \mathrm{~h}$, suggesting that the reaction rate increased as the reaction progressed. This result suggests that not only the $\mathrm{CH}_{3} \mathrm{CN}$ solvent but also ethylamine and py-THQ, which were produced as the reaction progressed, would act as polar and Lewis-basic additives in this hydrogenation reaction.

The deuterium-hydrogen exchange reaction between $\mathrm{H}_{2}$ and $\mathrm{D}_{2} \mathrm{O}$ was performed under standard conditions to clarify

\section{Table 3}

Reusability tests of PdNPore in the reduction of quinoline a. under standard conditions for $8 \mathrm{~h}$, the yield of product $2 \mathrm{a}$ was determined to be $20 \%$. Then, half of the reaction solution was transferred to another reaction vessel and continuously stirred for $16 \mathrm{~h}$. No change in the yield of $\mathbf{2 a}$ was observed in the absence of a solid catalyst. In contrast, a $91 \%$ yield of 2 a was obtained in the reaction of the residual solution containing the PdNPore catalyst. This result indicates that no Pd atoms were leached into the reaction solution, therefore confirming that the catalysis proceeded heterogeneously. Inductively coupled plasma-mass spectrometry (ICP-MS) measurements were used to further confirm that no Pd leached from the PdNPore catalyst (detection limit of $0.01 \times 10^{-6}$ ).

To further explore the practical applicability of our method, the chemoselective hydrogenation of quinoline was scaled up to the gram scale, and the result is shown in Scheme 4. When $1.29 \mathrm{~g}$ of $1 \mathrm{a}$ was treated under standard conditions, $1.16 \mathrm{~g}$ of py-THQ product 2a was obtained with $87 \%$ yield; this yield was slightly lower than that obtained in the small-scale experiments.

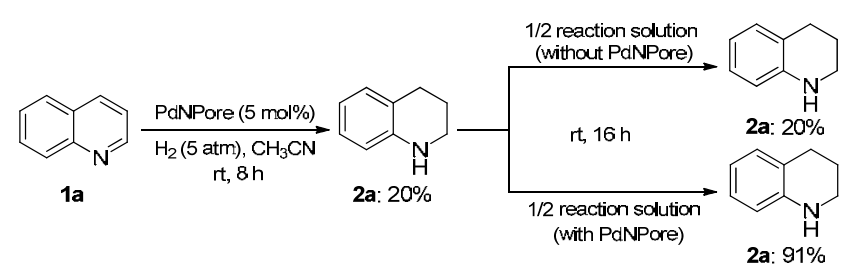

Scheme 3. Leaching test of PdNPore catalyst in the hydrogenation of 1a.

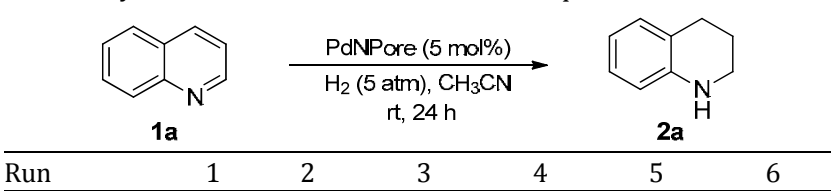

\begin{tabular}{ccccccc}
\hline & 1 & 2 & 3 & 4 & 5 & 6 \\
\hline Yield $^{\mathrm{b}}(\%)$ & 93 & 93 & 92 & 92 & 91 & 93
\end{tabular}

a Reaction conditions: quinoline (1a, $0.5 \mathrm{mmol})$, PdNPore (5 mol\%), $\mathrm{H}_{2}$ (5 atm), in $\mathrm{CH}_{3} \mathrm{CN}(3.0 \mathrm{~mL})$ at room temperature for $24 \mathrm{~h}$. b Isolated yield.

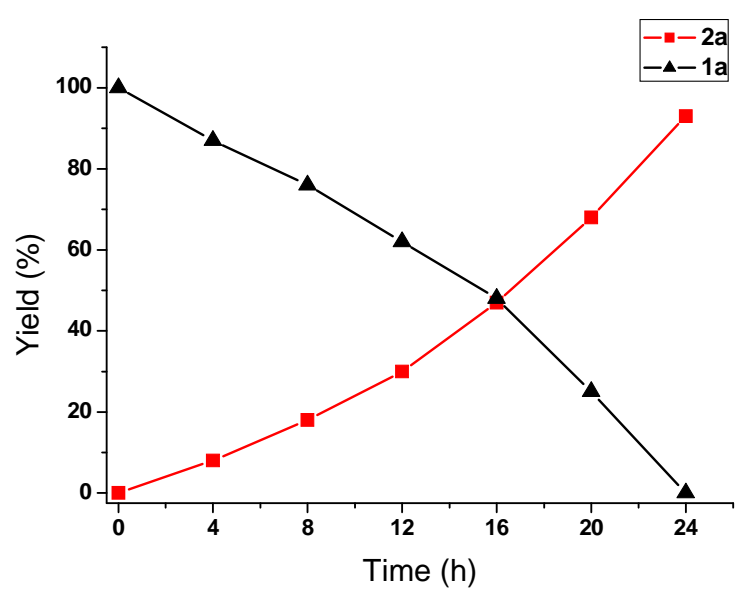

Fig. 1. Kinetic curves for quinoline hydrogenation with PdNPore catalyst. 


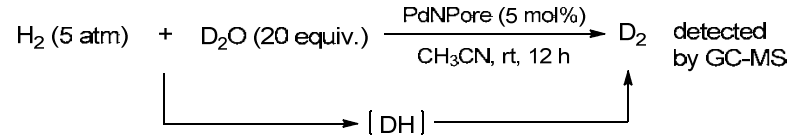

Scheme 5. Deuterium-hydrogen exchange reaction.

whether or not the hydrogenation involves Pd-H species generated through the heterolytic cleavage of $\mathrm{H}_{2}$ gas on PdNPore assisted by a polar and Lewis-basic additive, which might act as a weak nucleophile (Scheme 5). The formation of $\mathrm{D}_{2}$ gas was detected by gas chromatography-mass spectrometry (GC-MS) (Fig. S5); $\mathrm{D}_{2}$ is considered to be produced through the formation of DH. As shown in Scheme 6, adsorption of $\mathrm{H}_{2}$ would occur on the surface of PdNPore, and then a base would capture $\mathrm{H}^{+}$ions after the heterolytic splitting of $\mathrm{H}-\mathrm{H}$ bonds (A), producing [H-base] ${ }^{+}$and the $\mathrm{Pd}-\mathrm{H}^{-}$intermediate $\mathbf{B}$. If $\mathrm{D}_{2} \mathrm{O}$ is present in the reaction medium, the $\mathrm{Pd}-\mathrm{H}^{-}$intermediate $\mathbf{B}$ would react with $\mathrm{D}_{2} \mathrm{O}$ to release $\mathrm{DH}$ gas. Then, the in situ-generated DH would further undergo heterolytic cleavage to generate the $\mathrm{Pd}-\mathrm{D}^{-}$intermediate $\mathrm{C}$, which would subsequently react with $\mathrm{D}_{2} \mathrm{O}$ to release $\mathrm{D}_{2}$ gas.

Deuterium-labeling experiments were performed to further explore the mechanism behind the excellent activity and chemoselectivity in the quinoline hydrogenation provided by the PdNPore catalyst. The deuterium-labeled product $\mathbf{2 a}-\boldsymbol{d}_{\mathbf{3}}$ was obtained in $85 \%$ yield, with $100 \%$ deuterium incorporation at the 2-, 3-, and 4- three positions, when the hydrogenation of quinoline 1a was performed under $\mathrm{D}_{2}$ atmosphere under standard conditions (Scheme 7, Eq. (1)). The deuterium-labeled product $\mathbf{2 a - \boldsymbol { d } _ { 3 }}$ was obtained in $82 \%$ yield, with $62 \%$ deuterium incorporation at all the 2-, 3-, and 4- positions, when the deuterium-labeling experiment was conducted in the presence of two equivalents of $\mathrm{H}_{2} \mathrm{O}$ (Scheme 7, Eq. (2)). Non-deuterated 2a was obtained when a large amount of $\mathrm{H}_{2} \mathrm{O}$ (20 equiv.) was added to the reaction mixture (Scheme 7, Eq. (3)). These results indicate that the D-H exchange reaction between $\mathrm{D}_{2}$ and $\mathrm{H}_{2} \mathrm{O}$ proceeded very rapidly to produce $\mathrm{H}_{2}$ gas; therefore, the hydrogenation of quinoline 1a took place in the presence of both $\mathrm{D}_{2}$ and $\mathrm{H}_{2}$. Large amounts of $\mathrm{H}_{2}$ were generated when a large amount of $\mathrm{H}_{2} \mathrm{O}$ (20 equiv.) was added to the

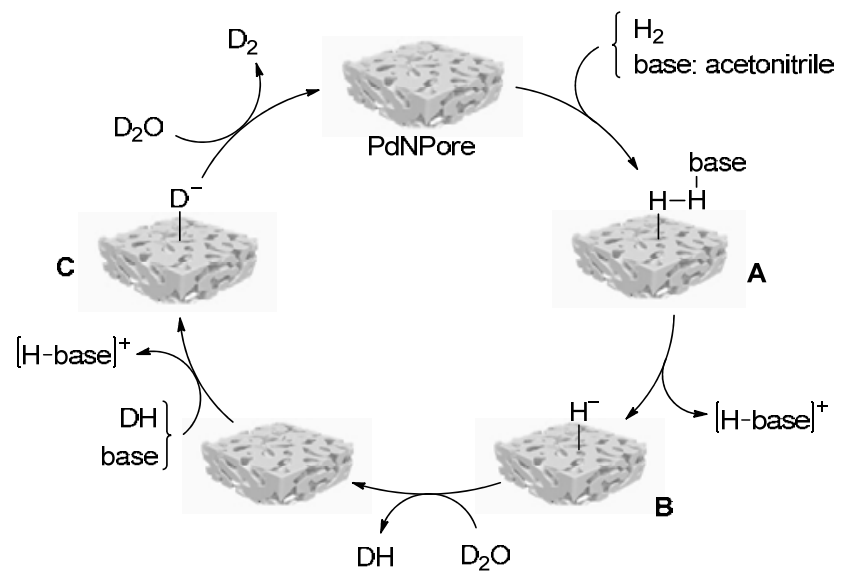

Scheme 6. Proposed mechanism for the deuterium-hydrogen exchange reaction.

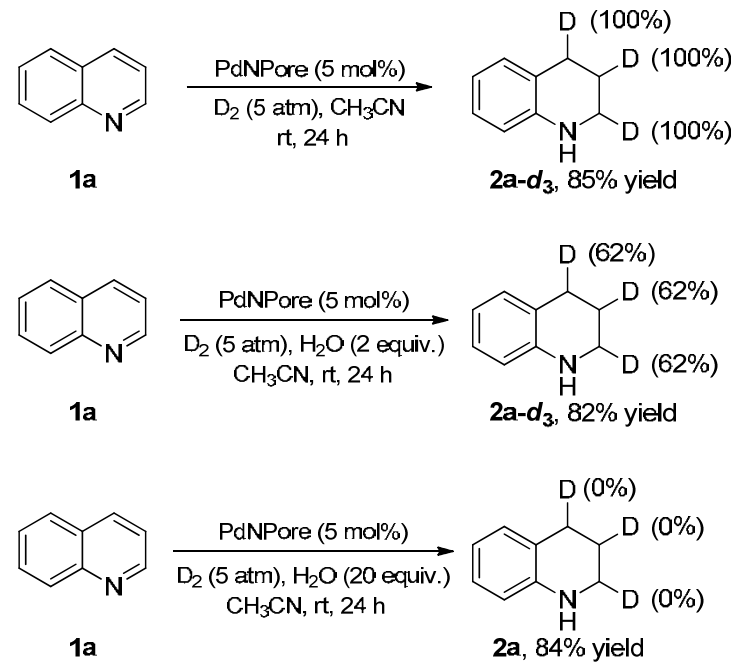

Scheme 7. Deuterium-labeling experiments.

reaction mixture, leading to the formation of the non-deuterated product 2 a. These results provide clear evidence for the heterolytic $\mathrm{H}_{2}$ splitting on the surface of PdNPore in the hydrogenation of quinolines.

\section{Conclusions}

In conclusion, we have demonstrated for the first time that the unsupported PdNPore is an efficient heterogeneous catalyst for the chemoselective hydrogenation of quinolines. Good to excellent yields of py-THQs were obtained, with excellent chemoselectivities under low $\mathrm{H}_{2}$ pressures and temperatures. The PdNPore catalyst could be easily recovered and reused several times without any loss of activity. To the best of our knowledge, this is the first report of heterolytic $\mathrm{H}_{2}$ splitting on the surface of heterogeneous catalysts in the hydrogenation of quinolines. Mechanistic analyses revealed that the heterolytic cleavage of the $\mathrm{H}-\mathrm{H}$ bonds on PdNPore and the in situ-generated $\mathrm{Pd}-\mathrm{H}$ species play an important role in the very high chemoselectivity achieved with the present catalyst. The unique features of the PdNPore catalyst (low $\mathrm{H}_{2}$ pressures and temperatures, high chemoselectivity, good functional group tolerance, high stability, and lack of leaching) make this material more useful for laboratory and industrial applications.

\section{References}

[1] P. N. Rylander, Catalytic Hydrogenation in Organic Syntheses, Academic Press, New York, 1979.

[2] P. G. Andersson, I. J. Munslow, Modern Reduction Methods, Wiley, New York, 2008.

[3] Z. Chen, J. Chen, Y. Li, Chin. J. Catal., 2017, 38, 1108-1126.

[4] L. Landenna, A. Villa, R. Zanella, C. Evangelisti, L. Prati, Chin. J. Catal., 2016, 37, 1771-1775.

[5] H. U. Blaser, C. Malan, B. Pugin, F. Spindler, H. Steiner, M. Studer, Adv. Synth. Catal., 2003, 345, 103-151.

[6] J. G. de Vries, C. J. Elsevier, The Handbook of Homogeneous Hydrogenation, Wiley-VCH, Weinheim, 2007.

[7] R. E. Harmon, S. K. Gupta, D. J. Brown, Chem. Rev., 1973, 73, 21-52 


\section{Graphical Abstract}

Chin. J. Catal., 2018, 39: 1746-1752 doi: 10.1016/S1872-2067(18)63151-1

\section{Unsupported nanoporous palladium-catalyzed chemoselective hydrogenation of quinolines: Heterolytic cleavage of $\mathrm{H}_{2}$} molecule

Ye Lu, Yoshinori Yamamoto, Abdulrahman I. Almansour, Natarajan Arumugam, Raju Suresh Kumar, Ming Bao*

Dalian University of Technology, China; Tohoku University, Japan; Ritsumeikan University, Japan; King Saud University, Saudi Arabia

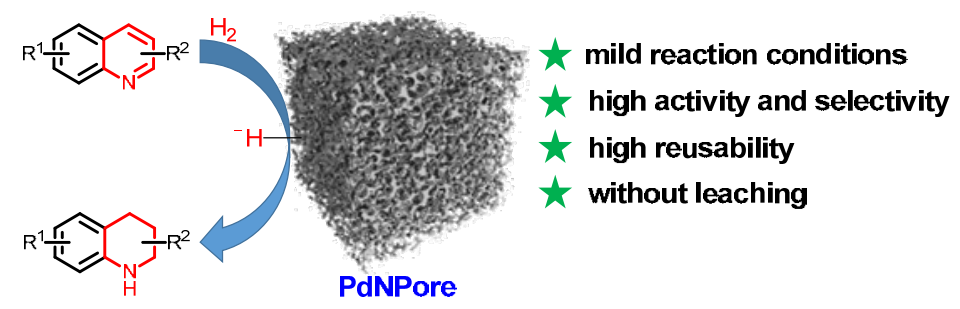

A non-toxic, robust, and recyclable nanoporous palladium catalyst was successfully used in the chemoselective hydrogenation of quinolines under mild reaction conditions.

[8] S. Nishimura, Handbook of Heterogeneous Catalytic Hydrogenation for Organic Synthesis, Wiley, New York, 2001.

[9] A. R. Katritzky, S. Rachwal, B. Rachwal, Tetrahedron, 1996, 52, 15031-15070.

[10] V. Sridharan, P. A. Suryavanshi, J. C. Menéndez, Chem. Rev., 2011, 111, 7157-7259.

[11] R. Yamaguchi, C. Ikeda, Y. Takahashi, K. Fujita, J. Am. Chem. Soc., 2009, 131, 8410-8412.

[12] W. J. Tang, J. Tan, L. J. Xu, K. H. Lam, Q. H. Fan, A. S. C. Chan, Adv. Synth. Catal., 2010, 352, 1055-1062.

[13] G. E. Dobereiner, A. Nova, N. D. Schley, N. Hazari, S. J. Miller, O. Eisenstein, R. H. Crabtree, J. Am. Chem. Soc., 2011, 133, 7547-7562.

[14] J. Wu, J. H. Barnard, Y. Zhang, D. Talwar, C. M. Robertson, J. Xiao, Chem. Commun., 2013, 49, 7052-7054.

[15] S. M. Lu, X. W. Han, Y. G. Zhou, J. Organomet. Chem., 2007, 692, 3065-3069.

[16] H. Zhou, Z. Li, Z. Wang, T. Wang, L. Xu, Y. He, Q. H. Fan, J. Pan, L. Gu, A. S. C. Chan, Angew. Chem. Int. Ed., 2008, 47, 8464-8467.

[17] T. Wang, L. G. Zhuo, Z. Li, F. Chen, Z. Ding, Y. He, Q. H. Fan, J. Xiang, Z. X. Yu, A. S. C. Chan, J. Am. Chem. Soc., 2011, 133, 9878-9891.

[18] R. Xu, S. Chakraborty, H. Yuan, W. D. Jones, ACS Catal., 2015, 5, 6350-6354.

[19] R. Adam, J. R. Cabrero-Antonino, A. Spannenberg, K. Junge, R. Jackstell, M. Beller, Angew. Chem. Int. Ed., 2017, 56, 3216-3220.

[20] M. Fang, R. A. Sánchez-Delgado, J. Catal., 2014, 311, 357-368.

[21] L. Zhang, X. Wang, Y. Xue, X. Zeng, H. Chen, R. Li, S. Wang, Catal. Sci. Technol., 2014, 4, 1939-1948.

[22] X. Wang, W. Chen, L. Zhang, T. Yao, W. Liu, Y. Lin, H. Ju, J. Dong, L. Zheng, W. Yan, X. Zheng, Z. Li, X. Wang, J. Yang, D. He, Y. Wang, Z. Deng, Y. Wu, Y. Li, J. Am. Chem. Soc., 2017, 139, 9419-9422.

[23] H. Mao, J. Ma, Y. Liao, S. Zhao, X. Liao, Catal. Sci. Technol., 2013, 3 , 1612-1617.

[24] M. M. Dell'Anna, V. F. Capodiferro, M. Mali, D. Manno, P. Cotugno, A. Monopoli, P. Mastrorilli, Appl. Catal. A, 2014, 481, 89-95.

[25] D. Ren, L. He, L. Yu, R. S. Ding, Y. M. Liu, Y. Cao, H. Y. He, K. N. Fan, J. Am. Chem. Soc., 2012, 134, 17592-17598.

[26] A. Sánchez, M. Fang, A. Ahmed, R. A. Sánchez-Delgado, Appl. Catal. A, 2014, 477, 117-124.
[27] M. Niu, Y. Wang, P. Chen, D. Du, J. Jiang, Z. Jin, Catal. Sci. Technol., 2015, 5, 4746-4749.

[28] A. Karakulina, A. Gopakumar, İ. Akçok, B. L. Roulier, T. LaGrange, S. A. Katsyuba, S. Das, P. J. Dyson, Angew. Chem. Int. Ed., 2016, 55, 292-296.

[29] F. Chen, A. E Surkus, L. He, M. M Pohl, J. Radnik, C. Topf, K. Junge, M. Beller, J. Am. Chem. Soc., 2015, 137, 11718-11724.

[30] Z. Wei, Y. Chen, J. Wang, D. Su, M. Tang, S. Mao, Y. Wang, ACS Catal., 2016, 6, 5816-5822.

[31] S. K. Moromi, S. M. A. H. Siddiki, K. Kon, T. Toyao, K. Shimizu, Catal. Today, 2017, 281, 507-511.

[32] H. Okazaki, K. Onishi, M. Soeda, Y. Ikefuji, R. Tamura, I. Mochida, Bull. Chem. Soc. Jpn., 1990, 63, 3167-3174.

[33] W. M. Czaplik, J. M. Neudörfl, A. J. von Wangelin, Green Chem., 2007, 9, 1163-1165.

[34] M. Tang, J. Deng, M. Li, X. Li, H. Li, Z. Chen, Y. Wang, Green Chem., 2016, 18, 6082-6090.

[35] Y. Cao, S. Mao, M. Li, Y. Chen, Y. Wang, ACS Catal., 2017, 7, 8090-8112.

[36] A. Wittstock, V. Zielasek, J. Biener, C. M. Friend, M. Bäumer, Science, 2010, 327, 319-322.

[37] K. M. Kosuda, A. Wittstock, C. M. Friend, M. Bäumer, Angew. Chem. Int. Ed., 2012, 51, 1698-1701.

[38] N. Asao, Y. Ishikawa, N. Hatakeyama, Menggenbateer, Y. Yamamoto, M. Chen, W. Zhang, A. Inoue, Angew. Chem. Int. Ed., 2010, 49, 10093-10095.

[39] M. Yan, T. Jin, Y. Ishikawa, T. Minato, T. Fujita, L. Y. Chen, M. Bao, N. Asao, M. W. Chen, Y. Yamamoto, J. Am. Chem. Soc., 2012, 134, 17536-17542.

[40] B. S. Takale, X. Feng, Y. Lu, M. Bao, T. Jin, T. Minato, Y. Yamamoto, J. Am. Chem. Soc., 2016, 138, 10356-10364.

[41] Y. Lu, X. Feng, B. S. Takale, Y. Yamamoto, W. Zhang, M. Bao, ACS Catal., 2017, 7, 8296-8303.

[42] M. Fang, N. Machalaba, R. A. Sánchez-Delgado, Dalton Trans., 2011, 40, 10621-10632.

[43] The product $2 \mathrm{j}$ can be utilized for syntheis of biologically active molecule, see: S. A. Biller, R. N. Misra, U.S. Patent 4843082, 1989. 


\title{
非负载纳米多孔钯催化喹啉及其衍生物的化学选择性氢化反应: $\mathrm{H}_{2}$ 分子异裂
}

\author{
卢 烨, Yoshinori Yamamoto ${ }^{\mathrm{a}, \mathrm{b}, \mathrm{c}}$, Abdulrahman I. Almansour ${ }^{\mathrm{d}}$, Natarajan Arumugam ${ }^{\mathrm{d}}$, \\ Raju Suresh Kumar ${ }^{d}$ ，包 明a, \\ ${ }^{\mathrm{a}}$ 大连理工大学精细化工国家重点实验室, 辽宁大连116023, 中国 \\ b 东北大学理学研究科化学系, 仙台980-8578, 日本 \\ c 立命馆大学科学技术研究所, 草津, 志贺525-8577, 日本 \\ d 沙特阿拉伯国王大学科学学院化学系, 2455信箱, 利雅得 11451 , 沙特阿拉伯
}

摘要: 纳米多孔金属是近十年发展起来的一类具有三维通孔结构的新型功能材料, 其由纳米尺度的细孔和韧带构成, 具 有极大的比表面积; 它还是一种无毒无载体的宏观材料, 并且易制备、易回收和重复利用, 因此作为高效的非均相催化剂 已逐渐引起人们的重视.

1,2,3,4-四氢喹啉是许多医药、农药、染料和天然产物的重要骨架. 通过喹啉及其衍生物的选择性加氢反应制备 $1,2,3,4-$ 四氢喹啉, 具有原子利用率高和原料易得等优点. 在过去, 已经开发了许多类型的均相和非均相催化体系, 并成功地用于 催化喹啉及其衍生物的选择性加氢反应. 尽管非均相催化体系具有诸多优点, 但仍存在 $\mathrm{H}_{2}$ 压力 $(10-50 \mathrm{~atm})$ 和反应温度 $\left(60-150{ }^{\circ} \mathrm{C}\right)$ 相对较高的缺点. 因此, 开发更加温和条件下的喹啉及其衍生物的选择性加氢反应具有重要意义. 此外, 在喹 啉及其衍生物的加氢反应过程中, $\mathrm{H}_{2}$ 分子在非均相催化剂表面的裂解模式, 即均裂还是异裂尚不清楚. 因此, 本文采用新 型非均相催化剂纳米多孔钯, 研究了喹啉及其衍生物的选择性加氢反应, 在相对较低的 $\mathrm{H}_{2}$ 压力(2-5 atm)和温度(室温 $\left.-50{ }^{\circ} \mathrm{C}\right)$ 下实现了目标反应, 高收率、高选择性地得到 $1,2,3,4$-四氢喹啉化合物.

在最佳反应条件下, 对底物的适用范围进行了考察. 结果表明, 各种含喹啉结构单元的化合物均能顺利发生反应, 产 物收率在 62\%-95\%. 而且该反应对甲基、甲氧基、羟基、酯基、醛基、酰胺基、卤素 $(\mathrm{F}, \mathrm{Cl}$ 和 $\mathrm{Br}$ )等官能团具有较好的兼容 性. 苯环上取代基的电子效应对反应有一定的影响, 吸电子基有利于目标反应的进行. 反应完成后, 纳米多孔钯催化剂很 容易回收, 且循环使用多次后, 仍未见催化活性降低. 扫描电镜和透射电镜结果发现, 循环使用后的纳米多孔钯催化剂结 构没有发生明显改变, 表明其结构稳定. 浸出实验结果证明, 没有钯原子浸出到反应液中, 表明该纳米多孔钯催化反应属 于多相催化过程. 喹啉的选择性氢化反应被放大到克级的规模时, 目标产物的收率仅略有降低, 说明该方法具有很好的 实用性. 通过动力学实验发现, 随着反应的进行, 反应速率不断加快, 表明反应过程中生成的乙胺和 $1,2,3,4$-四氢喹啉同样 扮演着路易斯碱性添加剂的角色, 促进了反应的进行. 通过反应机理研究, 揭示了 $\mathrm{H}-\mathrm{H}$ 键在纳米多孔钯表面发生了异裂, 原位形成的Pd-H物种作为弱亲核试剂，对目标反应的选择性控制起到了至关重要的作用.

关键词: 纳米多孔材料; 钯; 喹啉; 化学选择性氢化; 多相催化剂

收稿日期: 2018-06-26. 接受日期: 2018-07-29. 出版日期: 2018-11-05.

*通讯联系人. 电话: (0411)84986180; 传真: (0411)84986181; 电子信箱: mingbao@dlut.edu.cn

基金来源：国家自然科学基金(21573032, 21773021); 中央高校基本科研业务费专项资金(DUT17ZD212); 沙特国王大学国际合作 项目(ISPP\#0048).

本文的电子版全文由Elsevier出版社在ScienceDirect上出版(http://www.sciencedirect.com/science/journal/18722067). 